Document downloaded from:

http://hdl.handle.net/10251/105476

This paper must be cited as:

Ferrer-Polonio, E.; Carbonell Alcaina, C.; Mendoza Roca, JA.; Iborra Clar, A.; Alvarez Blanco, S.; Bes-Piá, M.; Pastor Alcañiz, L. (2017). Brine recovery from hypersaline wastewaters from table olive processing by combination of biological treatment and membrane technologies. Journal of Cleaner Production. 142:1377-1386.

doi:10.1016/j.jclepro.2016.11.169

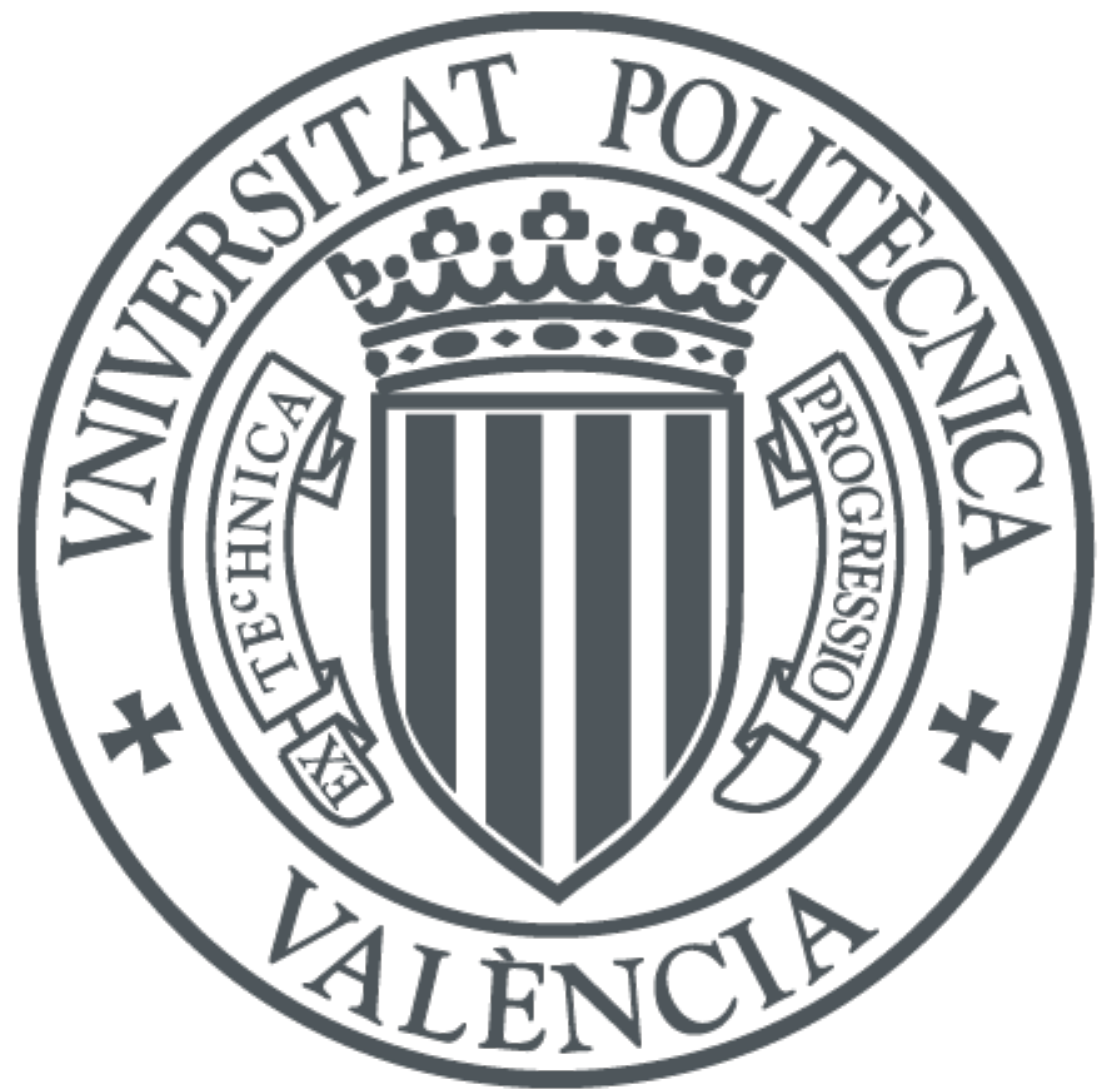

The final publication is available at

http://doi.org/10.1016/j.jclepro.2016.11.169

Copyright Elsevier

Additional Information 


\section{Brine recovery from hypersaline wastewaters from table olive processing by combination of biological treatment and membrane technologies}

E. Ferrer-Polonio ${ }^{\mathrm{a}, *}$, C. Carbonell-Alcaina ${ }^{\mathrm{a},{ }^{*}}$, J.A. Mendoza-Roca ${ }^{\mathrm{a}}$, A. Iborra-Clar ${ }^{\mathrm{a}}$, S. Álvarez-Blanco ${ }^{\mathrm{a}}$, A. Bes-Piáa ${ }^{2}$ L. Pastor-Alcañiz ${ }^{\mathrm{b}}$

a Instituto de Seguridad Industrial, Radiofísica y Medioambiental, Universitat Politècnica de València, Camino de Vera s/n, 46022 Valencia.

b Depuración de Aguas del Mediterráneo, Avda. Benjamin Franklin, 21, Parque Tecnológico, 46980 Paterna, Spain.

* Corresponding authors: Instituto de Seguridad Industrial, Radiofísica y Medioambiental Universitat Politècnica de València Camino de Vera s/n 46022 Valencia. Tel. +34 963877630 Fax +34963877639.

e-mail address: evferpo@posgrado.upv.es,carcaral@alumni.upv.es

\section{Abstract}

The fermentation brines from table olive processing (FTOP) are hypersaline effluents (conductivities higher than $75 \mathrm{mS} \cdot \mathrm{cm}^{-1}$ ) with high organic matter concentrations (COD around $10 \mathrm{~g} \cdot \mathrm{L}^{-1}$ ), which also include phenolic compounds (between 700 and $1500 \mathrm{mg} \mathrm{TY} \cdot \mathrm{L}^{-}$ ${ }^{1}$ ). In this work, an integrated process for the FTOP reuse as brine in the table olive processing has been evaluated. This integrated process consisted of a biological treatment followed by a membrane system, which included ultrafiltration (UF) plus nanofiltration (NF). The biological treatment was carried out by $6 \mathrm{~L}$ laboratory sequencing batch reactor (SBR). UF and NF were performed in laboratory plants for flat membranes of 0.0125 and $0.0072 \mathrm{~m}^{2}$, 
respectively. Each stream generated during the FTOP treatment (SBR effluent, and UF and NF permeates) were evaluated. The SBR eliminated around $80 \%$ of COD and $71 \%$ of total phenols concentration. In the final NF permeate the COD concentration was lower than 125 $\mathrm{mg} \cdot \mathrm{L}^{-1}$; while the turbidity, colour and phenolic compounds, were completely removed.

Keywords: Hipersaline effluents; phenolic compounds; biological treatment; ultrafiltration; nanofiltration.

\section{Nomenclature:}

HRT Hydraulic retention time (days)

SRT Sludge retention time (days)

COD Chemical oxygen demand $\left(\mathrm{mg} \cdot \mathrm{L}^{-1}\right)$

T.Ph Total phenols $\left(\mathrm{mg} \mathrm{TY} \cdot \mathrm{L}^{-1}\right)$

$\mathrm{Cl}^{-} \quad$ Chloride $\left(\mathrm{mg} \cdot \mathrm{L}^{-1}\right)$

$\mathrm{N}_{\mathrm{T}} \quad$ Total nitrogen $\left(\mathrm{mg} \cdot \mathrm{L}^{-1}\right)$

$\mathrm{P}_{\mathrm{T}} \quad$ Total phosphorus $\left(\mathrm{mg} \cdot \mathrm{L}^{-1}\right)$

SS $\quad$ FTOP suspended solids $\left(\mathrm{mg} \cdot \mathrm{L}^{-1}\right)$

VSS $\quad$ FTOP volatile suspended solids $\left(\mathrm{mg} \cdot \mathrm{L}^{-1}\right)$

MLSS $\quad$ Mixed liquor suspended solids $\left(\mathrm{mg} \cdot \mathrm{L}^{-1}\right)$

MLVSS Mixed liquor volatile suspended solids $\left(\mathrm{mg} \cdot \mathrm{L}^{-1}\right)$

F/M Food-to-microorganism ratio $\left(\mathrm{kg} \mathrm{COD} \cdot \mathrm{kg} \mathrm{MLVSS}^{-1} \cdot \mathrm{d}^{-1}\right)$

VRF Volume reduction factor

TMP Transmembrane pressure (bar) 


\section{INTRODUCTION}

Industrial activity related to the olive processing is one of the most important economic activities in Mediterranean countries such as Spain, Italy, Greek, Tunisia and Morocco (Moussavi et al., 2010a). Among these activities, table olive processing (TOP) is included. Total world production of table olives in 2014 was close to 2,600,000 tonnes. Spain was the greatest producer during 2014 (around 22.1\%), followed by Turkey and Egypt (around 16.6\% and $15.4 \%$ respectively) (“International Olive Council. 2016).

TOP objective is to remove the natural olive bitterness. This aim is performed through three steps. In the first step, named debittering, olives are submerged into a $\mathrm{NaOH}$ solution (1-2\% w/v) during 8-12 hours. Over this period the oleuropein (the phenolic compound that provides bitterness (Marsilio and Lanza, 1998)) is hydrolysed. Rinsing cycles are carried out in the second step to remove the alkaline solution. At the end, olives are submerged in brine (4-8\% w/v of $\mathrm{NaCl}$ ) for several months. Organoleptic properties of olives fruits are improved in this step, which is named fermentation. The global TOP wastewaters (TOPW) amount generated during the manufacturing process, is between 3.9 and $7.5 \mathrm{~m}^{3}$ per tonne of green olives (Kopsidas, 1992). These large quantities of wastewater contain high organic load, which includes high concentrations of phenolic compounds. The TOPW management is an important environmental problem, because these effluents are traditionally either discharged untreated into the sea or rivers, or stored in evaporation ponds. Alternatively, the TOPW is transported to large municipal wastewater treatment plants for its dilution; however this practice entails serious problems in these treatment plants, since salinity and phenolic compounds cause toxic effects to the biomass of the reactors. Nowadays, strict environmental 
regulations require the appropriate treatment for such effluents, so that efficient and environmentally sustainable treatments are demanded.

Debittering and rinsing wastewaters are generated between September and November, due to the seasonally olive recollection. On the contrary, the fermentation wastewater from table olive processing (FTOP) is produced throughout the year in the packaging plants (RomeroBarranco et al., 2001). That fact, together with the FTOP wastewater characteristics (pH around 4, 70-90 $\mathrm{mS} \cdot \mathrm{cm}^{-1}$ of conductivity, 6-21 $\mathrm{g} \mathrm{O}_{2} \cdot \mathrm{L}^{-1}$ of COD and total phenols (T.Ph) concentration between $700-1500 \mathrm{mg} \mathrm{TY} \cdot \mathrm{L}^{-1}$ ), makes appropriate segregate these effluents to treat them separately. The reuse of the spent FTOP, as a new fermentation step or solution packaging, has been studied in some investigations through dilution of these effluents. Nevertheless, the presence of metabolites interferes with the new fermentation process (Romero-Barranco et al., 2001) and organoleptic properties of the olives can be affected (Brenes et al., 1989); therefore FTOP treatment is necessary.

Some authors have proposed physico-chemical techniques for osmotic solutions management like electro-coagulation (García-García et al., 2011), ozonation (Moussavi et al., 2010b) or Fenton's reagent (Rivas et al., 2003), for organic matter removal. However, these techniques are very expensive and are not recommended for large volumes (Lobos et al., 2008). Biological treatment offers advantages over other wastewater treatments, since it is economic and environmental friendly.

The FTOP biological treatment is a complicated process due to high phenolic compounds concentrations and high salinity, that can inhibit the cellular activity of the biomass (Haddadi and Shavandi, 2013; Sayadi et al., 2000; Wang et al., 2014). Some authors have reported biological treatments for brine solutions (Kargi and Dinçer, 1998; Sharrer et al., 2007; Woolard and Irvine, 1995) and phenolic wastewaters (El-Naas et al., 2009; Sivasubramanian 
and Namasivayam, 2015), which include specialized cultures such as halophilic microorganisms. Nevertheless, in these studies simulated wastewater (with one or two phenolic compounds) or diluted wastewater, are usually used.

Although biological olive oil mill wastewater treatment has been extensively studied (Chiavola et al., 2014; Günay and Çetin, 2013), there are only a few of research papers dealing with the biological treatment of TOP wastewaters, and in these papers the FTOP is often excluded: e.g. Aggelis et al. (2001) reported about the biological treatment of debittering wastewaters, Maza-Márquez et al. (2013) treated the olive washing effluents and Rivas et al. (2000) the global wastewater excluding fermentation brines. Despite these difficulties, in a previous work (Ferrer-Polonio et al., 2015) the start-up of sequential batch reactor (SBR) treating FTOP was carried out successfully. After biomass acclimation period, the COD removal percentage was around $80 \%$. Thus, the FTOP has non-biodegradable organic matter that cannot be eliminated in the biological treatment. This is the reason why techniques to remove the recalcitrant organic content are necessary. Adsorption with carbon (Dąbrowski et al., 2005; Kumar et al., 2011) or polymeric resins (Maretto et al., 2014; Petrotos et al., 2012) and chemical oxidation techniques (Vlyssides et al., 2004), are viable techniques that remove COD, including phenolic compounds. However, membrane processes have additional advantages, such as the capacity to remove the suspended solids and microorganisms (Ahmad et al., 2004). Although there are numerous studies dealing with the use of membrane processes in wastewater treatment plants, as tertiary treatment, where clarified permeate and free microorganisms streams were obtained, allowing its reuse. Nevertheless, only a few studies of their application for hypersaline wastewaters treatment and reuse have been reported (El-Abbassi et al., 2014; Romero-Barranco et al., 2001).

The aim of this work was to perform an integral FTOP treatment that achieves the regeneration of this effluent, for its further reuse as fresh brine in a new fermentation step in 
the olive processing, or as conservation solution. Three processes were included in this integrated treatment; a direct biological treatment followed by two membrane process. The FTOP biological treatment was carried out by sequential biological reactor (SBR) and its purpose was the elimination of the degradable COD. Thus, the influence of the hydraulic retention time and the organic load on the COD and phenols removal efficiency was evaluated. The membrane treatment included ultrafiltration (UF) and nanofiltration (NF) processes and its finality was to eliminate completely the microorganisms coming from the biological treatment, colour, turbidity, suspended solids and T.Ph concentration. This treatment will also reduce the recalcitrant COD.

\section{MATERIALS AND METHODS}

\subsection{Wastewater}

Experiments were carried out with four fermentation brine samples (named from FTOP-1 to FTOP-4), provided by a table olive packaging industry located in Comunidad Valenciana (Spain). These FTOP were filtered by $60 \mu \mathrm{m}$ sieve, in order to reduce the suspended solids concentration and were characterized (Table 1). FTOPs were stored at $4^{\circ} \mathrm{C}$, until their use. The parameters were measured in triplicate. The average values and their calculated standard deviations have been presented.

The mean $\mathrm{pH}$ and conductivity for the four FTOPs were $4.3 \pm 0.2$ and $76.2 \pm 1.9 \mathrm{mS} \cdot \mathrm{cm}^{-1}$, respectively. Significant differences were observed for the others parameters presented in Table 1, because these characteristics depend on olive properties such as the crop variety (Kiai and Hafidi, 2014; Malheiro et al., 2011) and maturation degree (Ryan et al., 1999), as well as debittering and fermentation time (Brenes et al., 1995). The requirement of nutrients 
(nitrogen and phosphorous) in FTOPs was evaluated comparing with the relationship COD/N/P of 250/5/1. Due to the characteristics of the FTOPs no external nutrients were required.

Table 1. FTOP samples characterisation.

\begin{tabular}{lcccc}
\hline Parameter & FTOP-1 & FTOP-2 & FTOP-3 & FTOP-4 \\
\hline $\mathrm{pH}$ & $4.2 \pm 0.1$ & $4.5 \pm 0.1$ & $4.5 \pm 0.1$ & $4.0 \pm 0.1$ \\
Conductivity $\left(\mathrm{mS} \cdot \mathrm{cm}^{-1}\right)$ & $73.7 \pm 0.3$ & $76.0 \pm 0.5$ & $76.7 \pm 0.3$ & $78.3 \pm 0.7$ \\
Turbidity (NTU) & $186 \pm 15$ & $318 \pm 43$ & $117 \pm 9$ & $401 \pm 21$ \\
$\mathrm{COD}\left(\mathrm{g} \cdot \mathrm{L}^{-1}\right)$ & $14.16 \pm 0.10$ & $7.60 \pm 0.09$ & $6.23 \pm 0.08$ & $12.10 \pm 0.15$ \\
$\mathrm{~N}_{\mathrm{T}}\left(\mathrm{mg} \cdot \mathrm{L}^{-1}\right)$ & $275 \pm 13$ & $205 \pm 9$ & $447 \pm 21$ & $480 \pm 18$ \\
$\mathrm{P}_{\mathrm{T}}\left(\mathrm{mg} \cdot \mathrm{L}^{-1}\right)$ & $60 \pm 3$ & $35 \pm 3$ & $23 \pm 1$ & $41 \pm 5$ \\
$\mathrm{Cl}\left(\mathrm{g} \cdot \mathrm{L}^{-1}\right)$ & $33.41 \pm 0.13$ & $37.93 \pm 0.06$ & $38.60 \pm 0.08$ & $41.61 \pm 0.12$ \\
$\mathrm{~T} . \mathrm{Ph}\left(\mathrm{mg} \mathrm{TY} \cdot \mathrm{L}^{-1}\right)$ & $1554 \pm 34$ & $890 \pm 25$ & $687 \pm 36$ & $1326 \pm 32$ \\
$\mathrm{SS}\left(\mathrm{mg} \cdot \mathrm{L}^{-1}\right)$ & $971 \pm 62$ & $762 \pm 37$ & $2,466 \pm 52$ & $1,768 \pm 47$ \\
$\mathrm{VSS}\left(\mathrm{mg} \cdot \mathrm{L}^{-1}\right)$ & $523 \pm 16$ & $402 \pm 22$ & $1,646 \pm 32$ & $668 \pm 12$ \\
\hline
\end{tabular}

\subsection{Sequencing batch reactor}

The SBR start-up was carried out in a previous work (Ferrer-Polonio et al., 2015). In this investigation, the previous biomass acclimation of the FTOP was reported and the mechanical components and scheme of the SBR plant can be found. Gradual acclimation of salinity and phenolic compounds and high hydraulic retention time (HRT $=40$ days) were required to achieve high COD and T.Ph removal performance.

In the present work, the SBR was operated during 208 days with $6 \mathrm{~L}$ of volume reaction and one operating cycle per day, which included the following steps: filling ( $2 \mathrm{~min}$ ), reaction (1320 min), sedimentation (90 min), drawing (2 min), and idle (26 min). Feeding and drawing were carried out with peristaltic pumps. A mechanical stirrer and a compressor were connected during reaction phase. Compressor was connected to a porous diffuser located on 
the bottom of the reactor, which provided an aeration flow rate of $9 \mathrm{~L} \cdot \mathrm{min}^{-1}$. The dissolved oxygen (DO) in the mixed liquor was controlled by a programmed automaton, which maintained it between 1.5 and $2.5 \mathrm{mg} \cdot \mathrm{L}^{-1}$. Sludge withdrawal was performed to have the mixed liquor volatile suspended solids around $3,500 \mathrm{mg} \cdot \mathrm{L}^{-1}$.

In the first operation period, the F/M ratio [Eq.(1)] was maintained practically constant by adjusting the feed flow rate. Therefore, the HRT varied with the fed FTOP.

$$
\mathrm{F} / \mathrm{M}=\frac{\mathrm{COD}_{\mathrm{FTOP}-\mathrm{i}} \cdot \mathrm{Q}_{\mathrm{i}}}{\mathrm{V}_{\mathrm{R}} \cdot \mathrm{MLVSS}}
$$

where $\mathrm{COD}_{\mathrm{FTOP}-\mathrm{i}}$ was the influent $\mathrm{COD}$ concentration $\left(\mathrm{mg} \cdot \mathrm{L}^{-1}\right)$ and $\mathrm{Q}_{\mathrm{i}}$ was the daily

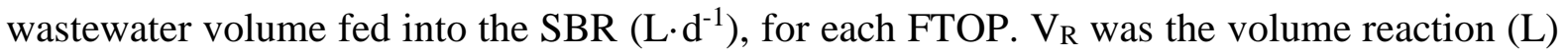
and MLVSS was the mixed liquor volatile suspended solids $\left(\mathrm{mg} \cdot \mathrm{L}^{-1}\right)$.

In the second operation period, the HRT was maintained constant and the F/M ratio increased because COD FTop-4 was higher than CODFtop-3. The COD and T.Ph removal efficiencies were also studied under these conditions.

Table 2 summarizes the operational conditions throughout the experimental periods. The SBR effluent was collected when FTOP-2 and FTOP-3 were fed (during 40 days) in order to use them as feed for the UF and NF processes.

Table 2. Operating conditions.

\begin{tabular}{|c|c|c|c|c|c|}
\hline Period & Sample & $\begin{array}{c}V_{\text {feed/draw }} \\
(\mathrm{mL})\end{array}$ & $\begin{array}{c}\text { HRT } \\
\text { (days) }\end{array}$ & 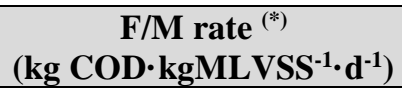 & $\begin{array}{c}\begin{array}{c}\text { Experimental time } \\
\text { (days) }\end{array} \\
\end{array}$ \\
\hline \multirow{3}{*}{1} & FTOP-1 & 150 & 40 & & $0-35$ \\
\hline & FTOP-2 & 290 & 20.7 & $0.106 \pm 0.017$ & $36-74$ \\
\hline & FTOP-3 & 360 & 16.7 & & $75-155$ \\
\hline 2 & FTOP-4 & 360 & 16.7 & $0.212 \pm 0.043$ & $156-208$ \\
\hline
\end{tabular}

$(*)$ These indicative values were calculated from a MLVSS rate between $3000-4000 \mathrm{mg} \cdot \mathrm{L}^{-1}$. 


\subsection{Ultrafiltration unit}

The SBR effluent has been treated by an automatically controlled UF unit equipped with an UF module for a flat sheet membrane (Rayflow Orelis, France). The control system could regulate automatically the transmembrane pressure (TMP), the cross flow velocity (CFV), and the temperature. The used UF conditions were $3 \mathrm{bar}, 2.2 \mathrm{~m} / \mathrm{s}$ and $25^{\circ} \mathrm{C}$. The UF module was configured to work with one membrane clipping in cross-flow mode. A membrane UP005 supplied by Microdyn Nadir (Germany), whose main characteristics are in Table 3, was used.

Table 3. Ultrafiltration and nanofiltration membranes characteristics.

\begin{tabular}{cccccc}
\hline Reference & Material & MWCO & Salt pass & $\begin{array}{c}\text { Active surface } \\
\left(\mathbf{m}^{\mathbf{2}}\right)\end{array}$ & $\begin{array}{c}\text { Permeability }^{* *} \\
\left(\mathbf{m}^{\mathbf{3}} \cdot \mathbf{m}^{-\mathbf{2}} \cdot \mathbf{s}^{-\mathbf{1}} \cdot \mathbf{b a r}^{-\mathbf{1}} \mathbf{)}\right.\end{array}$ \\
\hline UP005 & $\begin{array}{c}\text { Polyethersulfone } \\
\text { non hydrophilic }\end{array}$ & $5 \mathrm{kDa}$ & - & 0.0125 & $6.64 \times 10^{-6} \pm 0.03 \times 10^{-6}$ \\
NF245 & Polyamide & - & $1.0 \%{ }^{*}$ & 0.0072 & $1.19 \times 10^{-6} \pm 0.02 \times 10^{-6}$ \\
\hline
\end{tabular}

${ }^{*}$ Data provided by the manufacturer. Operating conditions: 2,000 $\mathrm{ppm} \mathrm{MgSO}_{4}$ feed, 9 bar and $25^{\circ} \mathrm{C}$.

** Experimental data. Linear relationship between pure water permeate flux and TMP at $25^{\circ} \mathrm{C}$.

During the UF process, the retentate stream was recycled back to the feed tank and the permeate stream was stored in a separated tank. The UF permeate was the feed for the NF unit. A Kern PKP precision balance (Kern, Germany) was used to monitor by weighing the permeate flux. The collected data were recorded by a data acquisition system.

The effluent filtration $(60 \mu \mathrm{m})$ was carried out as control method to ensure the flocs removal in case the settleability of the activated sludge worsened. During the UF of these samples volumes of $5.5 \mathrm{~L}$ were treated in different tests at the conditions described above. The UF tests were carried out up to a volume reduction factor (VRF) of 1.57 which is the maximum one reached by the equipment working with 5.5 liters. The final rejection volumes of these tests were mixed in order to use them again as membrane feed for the process study at a 
higher VRF. In this way, other different UF tests were run with 5.5 liters of the finals rejections of VRF of 1.57 until reaching a final VRF of 2.10. All the runs were performed with the same membrane piece.

Between tests, the membrane was cleaned with different solutions at $2.2 \mathrm{~m} \cdot \mathrm{s}^{-1}, 0.6$ bar and room temperature. The membrane cleaning protocol was the following: rinsing with osmotic water during 9 minutes, cleaning with basic solution of $\mathrm{NaOH}$ ( $\mathrm{pH}$ 11) (Panreac, Spain) recycling it during 30 minutes at $30^{\circ} \mathrm{C}$, rinsing with osmotic water during 9 minutes, cleaning with acid solution of citric acid (1\% w/v) (Panreac, Spain) recycling it during 5 minutes and a final rinsing with osmotic water during 9 minutes. Membrane permeability was considered to be cleaned if more than 95\% of its initial hydraulic permeability was recovered.

\subsection{Nanofiltration unit}

The permeate obtained in the UF unit was further treated in the NF unit. This unit was an automatic plant, equipped with an NF module for a flat sheet membrane designed in "Instituto de Seguridad Industrial, Radiofísica y Medioambiental”, ISIRYM (Spain) (Santafé-Moros and Gozálvez-Zafrilla, 2010). This plant can regulate automatically the CFV and temperature. The operating conditions were TMP of 15 bars, CFV of $1.5 \mathrm{~m} \cdot \mathrm{s}^{-1}$ and $25^{\circ} \mathrm{C}$ during 4 hours. A membrane NF245 supplied by DOW (USA), was used. Membrane characteristics it can be seen in Table 3. The NF tests were performed in a similar way as the UF experiments, but recycling permeate and retentate streams back to the feed tank. In order to measure the permeate flux, it was used the same precision balance as in the UF step, and the data were collected by the same method. The NF membrane was cleaned by rinses with tap water and osmotic water at $25^{\circ} \mathrm{C}$ without TMP, and without recirculation of any stream until the retentate had the same conductivity as the feed. After that, the retentate was recycled 
back to the feed tank and, at 1 bar, the membrane was rinsing with osmotic water until the membrane permeate had the same conductivity as the feed.

\subsection{Analysis.}

The characterizations of the effluent and the mixed liquor of the SBR were performed once a week. The parameters measured were the following: $\mathrm{pH}$, conductivity, colour, soluble COD (filtered to $0.45 \mu \mathrm{m}$ ), mixed liquor suspended solids (MLSS) and mixed liquor volatile suspended solids (MLVSS). Additionally the F/M ratio, MLVSS/MLSS, COD and T.Ph removal percentages [Eq.(2) and Eq.(3)] were calculated.

$$
\begin{aligned}
& \text { COD removal }(\%)=\frac{\mathrm{COD}_{\text {influent }}-\mathrm{COD}_{\text {effluent }}}{\mathrm{COD}_{\text {influent }}} \cdot 100 \\
& \text { T. Ph removal }(\%)=\frac{\mathrm{T} \cdot \mathrm{Ph}_{\text {influent }}-\mathrm{T} \cdot \mathrm{Ph}_{\text {effluent }}}{\mathrm{T} \cdot \mathrm{Ph}_{\text {influent }}} \cdot 100
\end{aligned}
$$

where the "influent" and "effluent" subscripts refer to concentration $\left(\mathrm{mg} \cdot \mathrm{L}^{-1}\right)$ in the FTOP and in the SBR effluent, respectively.

During the UF step, the parameters controlled in the initial feed, in the final retentate and in the membrane permeate were $\mathrm{pH}$, conductivity, turbidity, colour, soluble COD and T.Ph. In addition, the evolution of the soluble COD and the T.Ph concentration in permeate were controlled, taken samples at different times. During the NF step the controlled parameters were $\mathrm{pH}$, conductivity, colour, soluble COD and T.Ph for the initial feed (final UF permeate) and final permeate. The phenolic profile was obtained for the final UF and NF permeates. 
The effluent colour after biological, UF and NF treatments, was measured by the "FZ" parameter (Döepkens et al., 2001), which was calculated by Eq.(4), after diluting 40 times the samples:

$$
\mathrm{FZ}=\frac{\mathrm{A}_{436}^{2}+\mathrm{A}_{525}^{2}+\mathrm{A}_{620}^{2}}{\mathrm{~A}_{436}+\mathrm{A}_{525}+\mathrm{A}_{629}}
$$

where $A_{436}, A_{525}$ and $A_{620}$ were the absorbance measured at 436, 525 and $620 \mathrm{~nm}$.

To evaluate the membranes separation efficiency, COD and T.Ph rejections were determined according to Eq.(5):

$$
R_{i}(\%)=\left(1-\frac{C_{P i}}{C_{F i}}\right) \cdot 100
$$

where $R_{i}$ is the rejection of the parameter $i$ (COD or T.Ph) in \%, $C_{P i}$ is the concentration of parameter $i$ in the permeate stream and $C_{F i}$ is the concentration of parameter $i$ in the feed solution.

The $\mathrm{pH}$ and conductivity measurements were carried out with pH-Meter GLP 21+ and ECMeter GLP 31+ (both from Crison), respectively. The SS, VSS, MLSS and MLVSS were measured according to (APHA, 2005). The turbidity was determined with a Turbidimeter D112 from Dinko Instruments. The $\mathrm{N}_{\mathrm{T}}, \mathrm{P}_{\mathrm{T}}, \mathrm{Cl}^{-}$and soluble COD concentration were analyzed using kits and a Spectrophotometer DR600 (Hach Lange), after the appropriate dilutions to avoid interferences. The same spectrophotometer was used to measure $A_{436}, A_{525}$ and $A_{620}$. 


\section{Phenolic compounds.}

The T.Ph concentration was measured spectrophotometrically according to Folin-Ciocalteu method (Singleton et al., 1999); sodium carbonate (20\% w/v) from Panreac, Folin \& Ciocalteu's reagent and Tyrosol analytical standard, both from Sigma Aldrich, were used. The results were reported as equivalent tyrosol concentration $\left(\mathrm{mg} T \mathrm{TY} \cdot \mathrm{L}^{-1}\right)$.

Also the phenolic profile was obtained by high-performance liquid chromatography, with Jasco HPLC equipment, according to chromatographic method followed in a previous work (Ferrer-Polonio et al., 2016). Hydroquinone was added as internal standard, therefore it had a constant concentration in all samples analyzed. The FTOPs and the effluents (SBR and UF/NF permeate) were previously treated in order to extract phenols from the saline matrix, according to El-Abbassi et al. (2011).

\section{RESULTS AND DISCUSSION}

\subsection{SBR performance}

The mixed liquor temperature was $21.9 \pm 2.7^{\circ} \mathrm{C}$ during the experimental time (208 days). In this period the conductivity and the $\mathrm{pH}$ of the SBR effluent were $87.4 \pm 4.1 \mathrm{mS} \cdot \mathrm{cm}^{-1}$ and 8.2 \pm 0.2 , respectively. This high $\mathrm{pH}$ value (considering that the FTOPs was an acidic wastewater) was due to the organic acids biodegradation (lactic, malic, formic and acetic acid) contained in the FTOP samples (Parinos et al., 2007).

In Figure 1, the removal efficiencies of COD and T.Ph in the SBR and the final concentrations of COD and T.Ph. in the effluent can be seen. The vertical lines indicate the FTOP feeding change. 


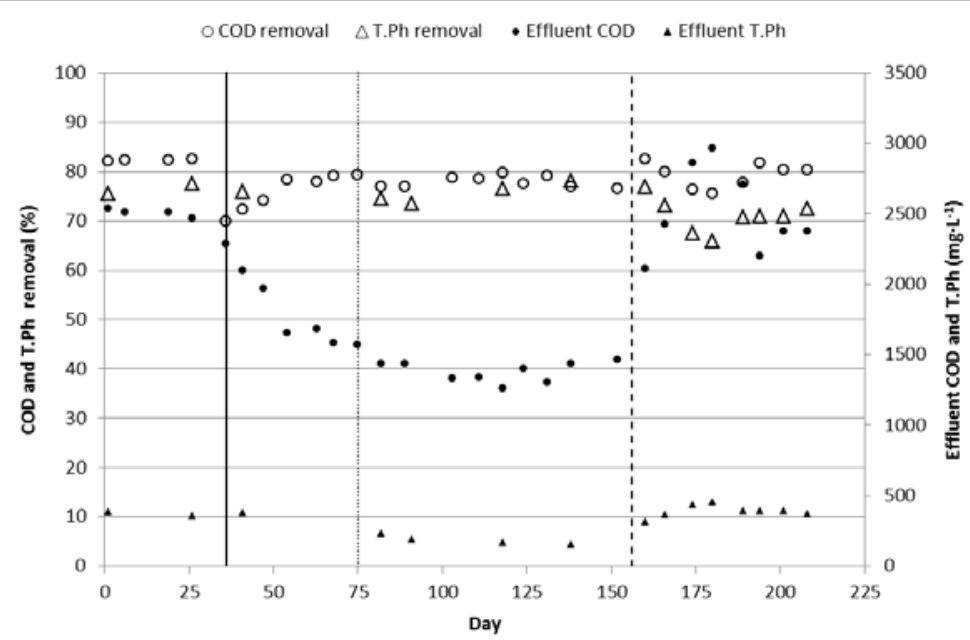

Figure 1. Evolution of the COD and T.Ph removal efficiency and the effluent COD and T.Ph concentration. Vertical lines: [-] FTOP-2; […..] FTOP-3; [- -] FTOP-4.

\subsubsection{Experimental Period-1}

As mentioned in the materials and method section, in the first experimental period (170 days) the F/M ratio was maintained in $0.12 \pm 0.01 \mathrm{~kg} \mathrm{COD} \cdot \mathrm{kg} \mathrm{MLVSS}^{-1} \cdot \mathrm{d}^{-1}$. The mean MLSS and MLVSS values were $5794 \pm 573$ and $3101 \pm 350 \mathrm{mg} \cdot \mathrm{L}^{-1}$, respectively. Under these operational conditions the MLVSS/MLSS ratio was maintained in $0.53 \pm 0.03$ and the sludge retention time (SRT) was 43 days.

Although the COD removal percentage remained in $79.1 \pm 2.1 \%$ in Period- 1 , COD effluent decreased since COD influent also decreased. In fact, the COD of FTOP-2 was almost the half of

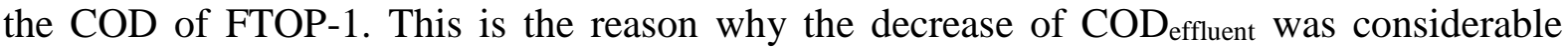

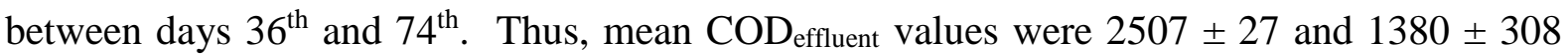
$\mathrm{mg} \cdot \mathrm{L}^{-1}$ when FTOP-1 and FTOP-3 were fed, respectively. Likewise, the same trend was observed for the T.Ph. The T.Ph removal percentage remained in $76.0 \pm 1.8 \%$ while mean T.Pheffluent decreased from $364 \pm 21$ to $180 \pm 34 \mathrm{mg} \cdot \mathrm{L}^{-1}$ when FTOP-1 and FTOP-3 were fed, respectively. The effluent colour was dark due to the oxidation of the phenolic compounds 
that remained after biological treatment under alkaline conditions, which is known as “enzymatic browning” (Segovia-Bravo et al., 2010, 2009). This phenomenon consists of the formation of compounds such as o-quinones, which can rapidly polymerize to form the melanin that produces dark brown coloration (Brenes Balbuena et al., 1988; Sayadi et al., 2000). The FZ parameter increased when T.Pheffluent increased. Thus, the means FZ values in the effluent were $0.12 \pm 0.01$ and $0.07 \pm 0.01$ when FTOP-1 and FTOP-3 were fed, respectively.

The phenolic profile for FTOP-3 and the effluent collected from the SBR, while FTP-3 was fed, are shown in Figure 2.
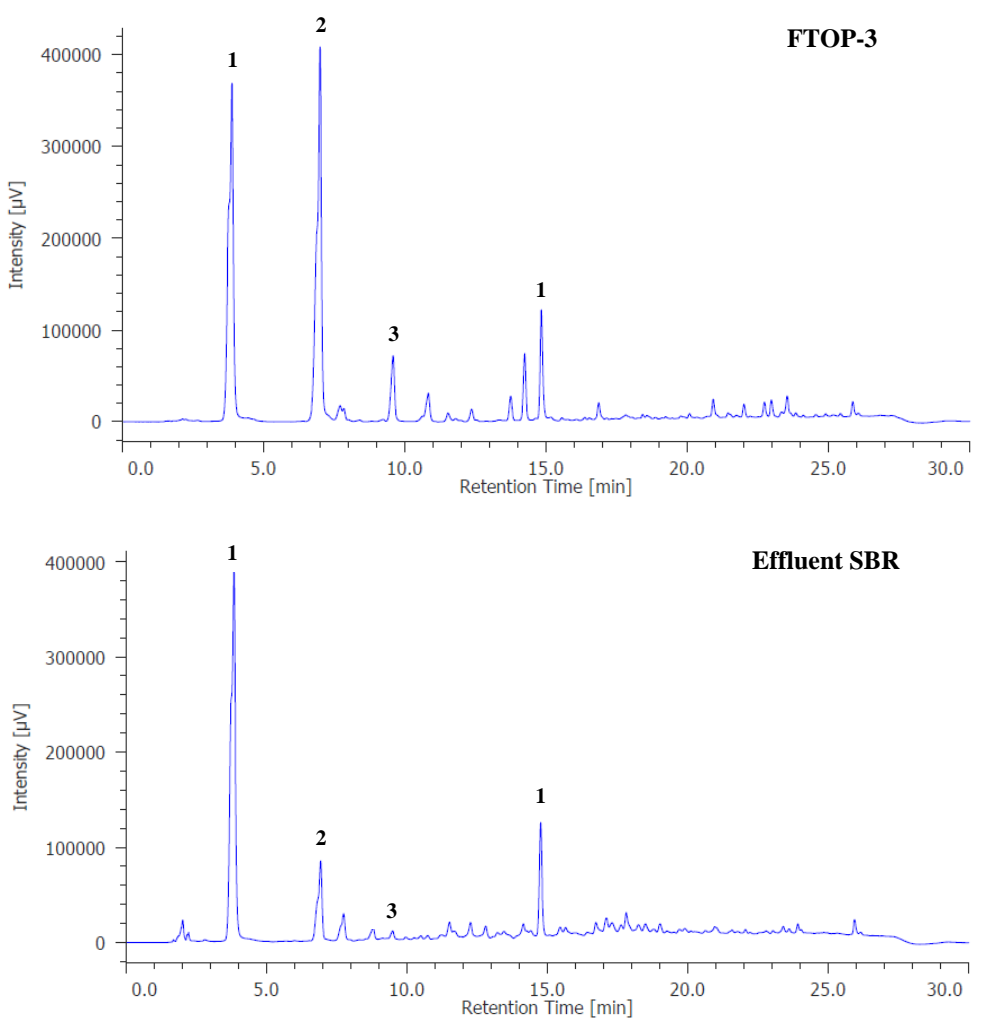

Figure 2. HPLC chromatograms for the effluent SBR and FTOP-3.

Peak identification: (1) Hydroquinone (internal standard); (2) Hydroxytyrosol; (3) Tyrosol. 
As it can be observed, hydroxytyrosol (HTY) was the main phenolic compound in FTOP-3. It also occurred in the other FTOPs samples (chromatograms not shown). Hydroxytyrosol concentration is explained by the hydrolysis of oleuropein (Othman et al., 2009), which is the main phenolic compound in olive fruits (De Castro and Brenes, 2001). Another phenolic compound present in all FTOPs was tyrosol (TY), which is produced from the hydrolysis of ligstroside. This composition agrees with those reported by other authors (Bouaziz et al., 2008; Brenes et al., 1995; Fendri et al., 2013). The presence of other phenolic compounds such as caffeic, gallic, p-hydroxyphenylacetic, vanillic..., which were not detected in the analysed samples, depends on the cultivar and olive maturation stage, as commented in subsection 2.1. In the SBR effluent collected to perform the UF/NF treatment, the T.Ph concentration was reduced around $84.7 \%$. This reduction is also checked in the phenolic profile as it is shown in Figure 2.

\subsubsection{Experimental Period-2}

In the second experimental period (last 52 days), the $\mathrm{F} / \mathrm{M}$ ratio was maintained in $0.19 \pm 0.01$ $\mathrm{kg}$ COD $\cdot \mathrm{kg} \mathrm{MLVSS}^{-1} \cdot \mathrm{d}^{-1}$. This increase in the organic load implied an increase in the biomass growth, and the SRT became 38 days for maintaining the MLVSS around 3000 $\mathrm{mg} \cdot \mathrm{L}^{-1}$. The MLVSS/MLSS ratio was maintained in $0.55 \pm 0.04$.

In the first days the effluent COD and T.Ph concentrations increased since both parameters were higher in FTOP-4 than in FTOP-3. As it happened in Period-1, when FTOP-2 was fed, several days were necessary in order to reach the stationary condition. After this period the average values of the COD and T.Ph removal percentages were $80.6 \pm 0.4 \%$ and $71.4 \pm 0.9 \%$, respectively. These results confirm that the biodegradable organic matter in the FTOPs was around $80 \%$ and that increasing HRT values and/or decreasing F/M ratios within the tested 
ranges did not enhance the SBR performance. Thus, a tertiary treatment is necessary to remove the recalcitrant organic matter of the FTOP.

\subsection{Membrane process}

\subsubsection{Ultrafiltration process}

The characterization of the SBR effluent collected to further treatment by membranes is shown in Table 4. As it was explained in section 2.3, the SBR effluent was previously filtered with a cartridge filter of $60 \mu \mathrm{m}$. In this step, the mean value of the turbidity reduction was $18.69 \pm 8.66 \%$ remaining a turbidity of $34.99 \pm 3.73$ NTU in the feed stream to the UF. The FZ parameter was reduced $1.61 \pm 1.35 \%$ and the rest of parameters were not affected.

Table 4. Streams characterization in the integrated FTOP treatment.

\begin{tabular}{lcccc}
\cline { 3 - 5 } Parameter & SBR & \multicolumn{2}{c}{ UF } & NF \\
\cline { 1 - 2 } \cline { 4 - 5 } treatment & $7.9 \pm 0.3$ & Permeate & Final feed & Permeate \\
\hline pH & $96.4 \pm 4.2$ & $101.9 \pm 0.1$ & $7.7 \pm 0.1$ & $7.8 \pm 0.1$ \\
Conductivity $\left(\mathrm{mS} \cdot \mathrm{cm}^{-1}\right)$ & $43.0 \pm 4.7$ & N.d. & $36.9 \pm 1.7$ & $90.9 \pm 1.3$ \\
Turbidity $(\mathrm{NTU})$ & $1922 \pm 103$ & $835 \pm 29$ & $3540 \pm 25$ & N.d. \\
COD $\left(\mathrm{mg} \cdot \mathrm{L}^{-1}\right)$ & $207 \pm 5$ & $43 \pm 2$ & $378 \pm 10$ & N.d. \\
T.Ph $\left(\mathrm{mg} \mathrm{TY} \cdot \mathrm{L}^{-1}\right)$ & $0.052 \pm 0.001$ & $0.006 \pm 0.001$ & $0.066 \pm 0.001$ & N.d. \\
FZ & & & & \\
\hline
\end{tabular}

N.d. = not detected

a) Permeate flux and membrane fouling

Figure 3 shows the evolution of the permeate flux with the VRF of three tests during the UF step: two tests concentrating from a VRF of 1.00 to 1.57 (UF1 and UF2) and the other on concentrating from a VRF of 1.57 to 2.10 (UF3). 


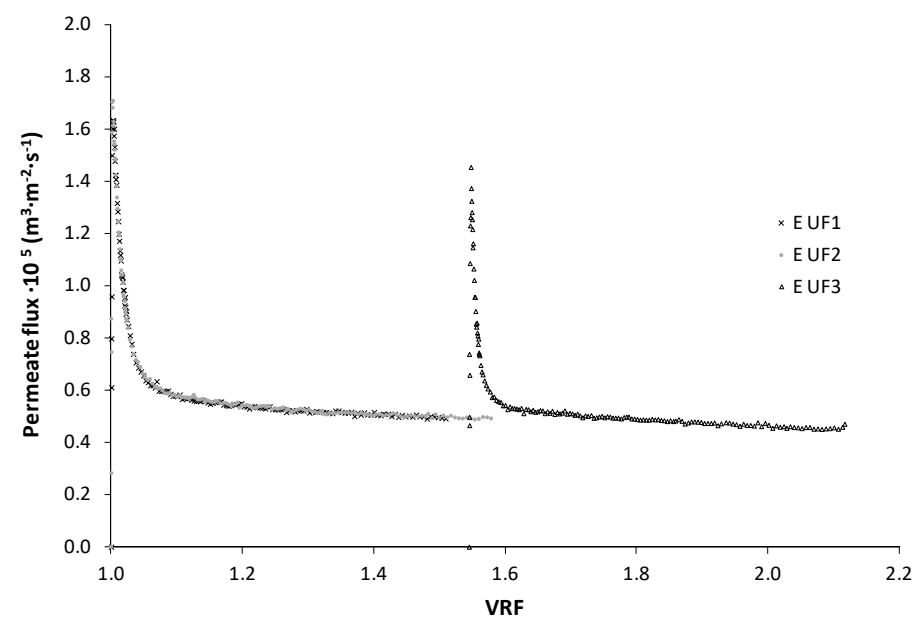

Figura 3. Evolution of the permeate flux with VRF in the UF process for two tests concentrating from a VRF of 1 to 1.57 (UF1 and UF2) and one UF test concentrating with the finals rejections of UF1 and UF2 until reaching a final VRF of 2.10 (UF3).

As it can be observed, the evolution of the permeate flux showed initial sharp declines followed by gradual diminutions over the time. The variation of the fluxes with the time followed the typical behavior described for severe fouling on membranes (Field et al., 1995; Ho and Zydney, 2000) operated at increasing feed (Van Der Bruggen and Vandecasteele, 2001). The achieved VRF correspond to a reduction of the initial feed volume of $52 \%$.

Comparing the two steps, it can be noted that the initial permeate fluxes in the tests increasing the VRF from 1.00 to 1.57 were higher than the initial flux in the test in that the VRF increased from 1.57 to 2.10 . Thus, the initial permeate flux values were $1.66 \times 10^{-5} \pm$ $0.01 \times 10^{-5} \mathrm{~m} \cdot \mathrm{s}^{-1}$ and $1.41 \times 10^{-5} \pm 0.06 \times 10^{-5} \mathrm{~m} \cdot \mathrm{s}^{-1}$, respectively. At the beginning of the tests, in the first stage of the membrane fouling, a permeate flux decline higher than $50 \%$ was observed. This initial fouling corresponded to the existence of pore blocking phenomena, which are mostly responsible for membrane fouling (Corbatón-Báguena et al., 2013). The final permeate flux for a VRF of 2.10 was $0.46 \times 10^{-5} \pm 0.01 \times 10^{-5} \mathrm{~m} \cdot \mathrm{s}^{-1}$, representing a flux decline around $70 \%$ of the initial one. In a previous work, the same UF membrane was used 
at the same conditions of TMP, CFV and temperature with the raw FTOP, i.e. without previous SBR treatment (Carbonell-Alcaina et al., 2016). In that study, the flux decline at the beginning of the test was around $77 \%$ of the initial one. This fact indicates that the SBR treatment reduces the particles that caused the pore blocking at the initial time of the UF treatment. Moreover, the final flux decline for the FTOP without previous SBR treatment was 85\%. This value is higher than that measured in the UF experiments using biologically treated FTOP. The membrane permeability was totally recovered after the application of the cleaning protocol in all the tests. This fact can be confirmed comparing the permeate flux evolution of UF1 and UF2 tests, in which the initial permeate flux and its evolution were practically the same. Nevertheless, the initial permeate flux in UF3 test was lower. It was not due to a reduction in the membrane permeability after the cleaning (permeability was totally recovered), but to the high feed concentration at the beginning of the experiment.

\section{b) COD and total phenols rejection}

In Figure 4 the evolution of the COD and T.Ph concentrations in the permeate flux can be observed.
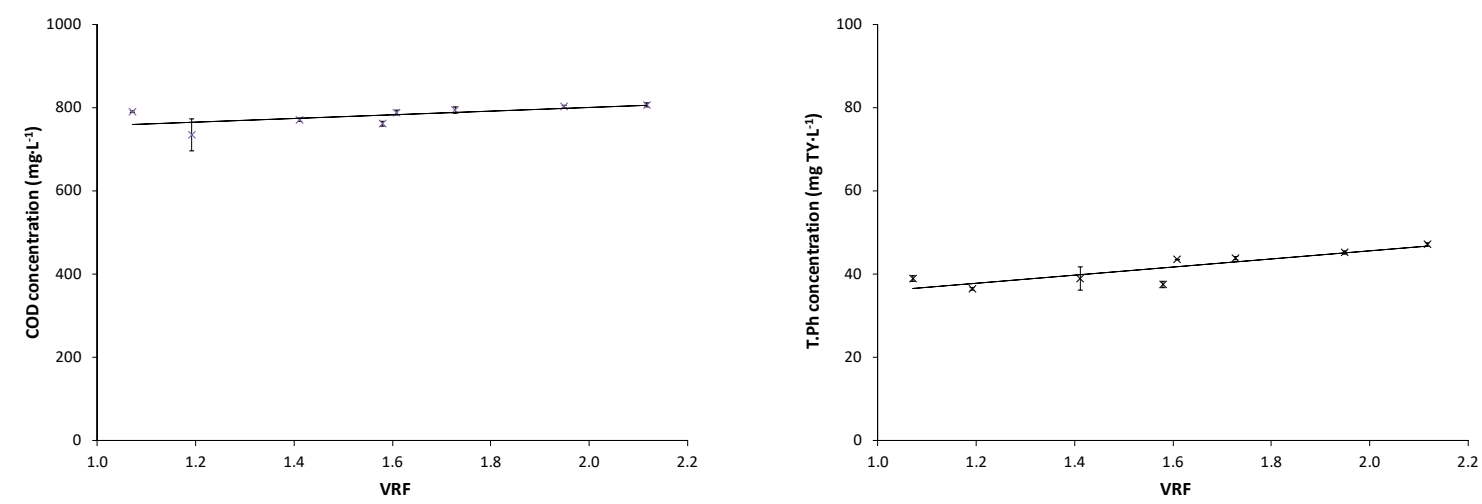

Figure 4. Evolution of the COD and T.Ph concentrations in the UF permeate flux. 
During the test, due to the membrane rejection, an increase in the feed concentration in terms of these parameters takes place (9.69\% and $21.19 \%$, respectively). The COD rejection was lower than the T.Ph rejection during the UF process, as illustrate in Figure 5. The raise of the membrane rejection, for increasing feed concentration, was also observed by other authors working with UF and NF membranes (Jiraratananon et al., 2000; Zuriaga-Agustí et al., 2014).

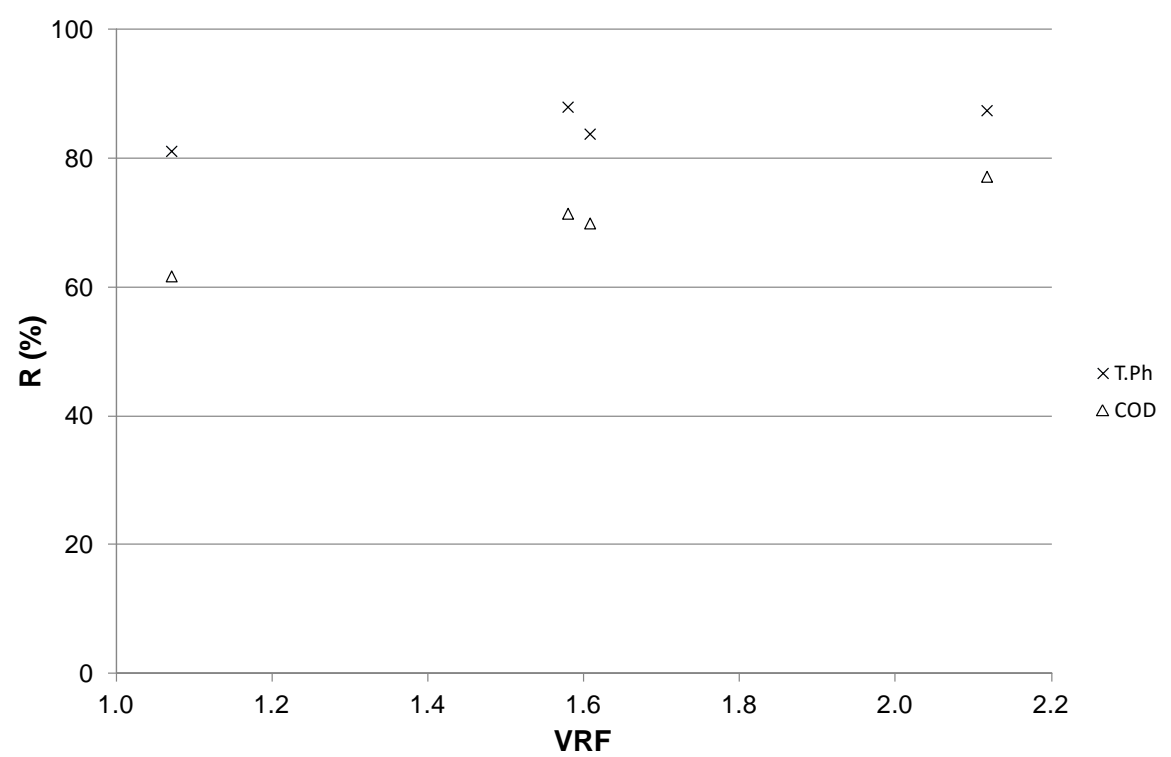

Figure 5. Evolution of T.Ph and COD rejection (R) during the UF as a function of VRF.

The characterizations of the final permeate and the final concentrated feed after the UF step are shown in Table4. The results showed that (for a VRF of 2.10) turbidity was not detected in the permeate stream, and a reduction of $56.5 \pm 2.3 \%$ and $79.1 \pm 0.5 \%$ were achieved for COD and T.Ph concentrations, respectively. Also, FZ, was reduced $88.7 \pm 0.2 \%$, while no effect on the $\mathrm{pH}$ and on the salts concentration was observed.

Figure 6 shows the phenolic profiles of the UF permeate. Comparing this figure with Figure 2 (SBR effluent) it can be observed that after the UF process, tyrosol was not detected and hydroxytyrosol peak decreased. It can be appreciated too that in Figure 2 there were more 
small unidentified peaks than in Figure 5, which shows that the UF membrane at these conditions rejects the great majority of the phenolic compounds.

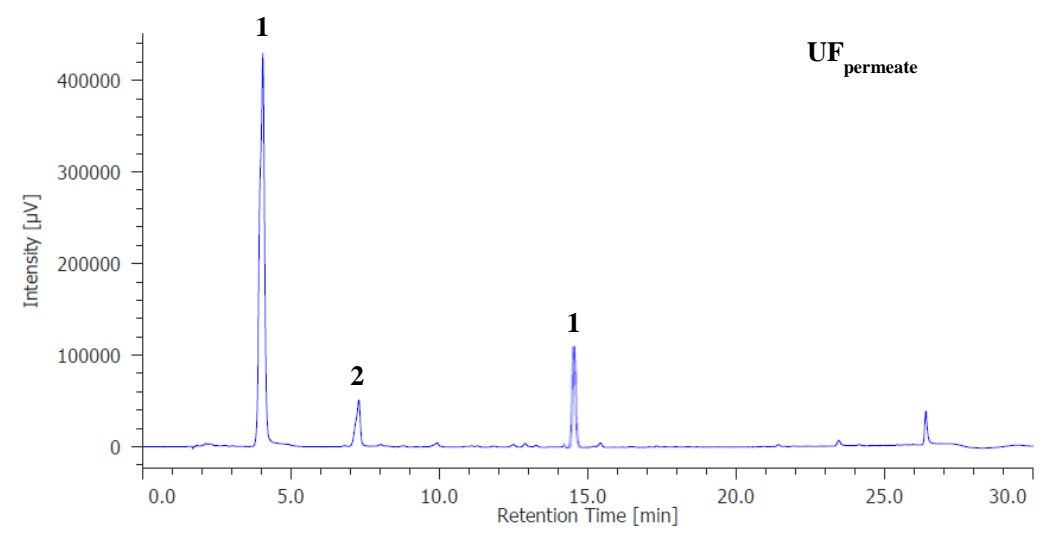

Figure 6. HPLC chromatograms for the UF permeate.

Peak identification: (1) Hydroquinone (internal standard); (2) Hydroxytyrosol; (3) Tyrosol.

\subsubsection{Nanofiltration process}

As it was described in section 2.4, the accumulated UF permeate was treated by NF. An example of the evolution of the permeate flux in the NF treatment is shown in Figure 7.

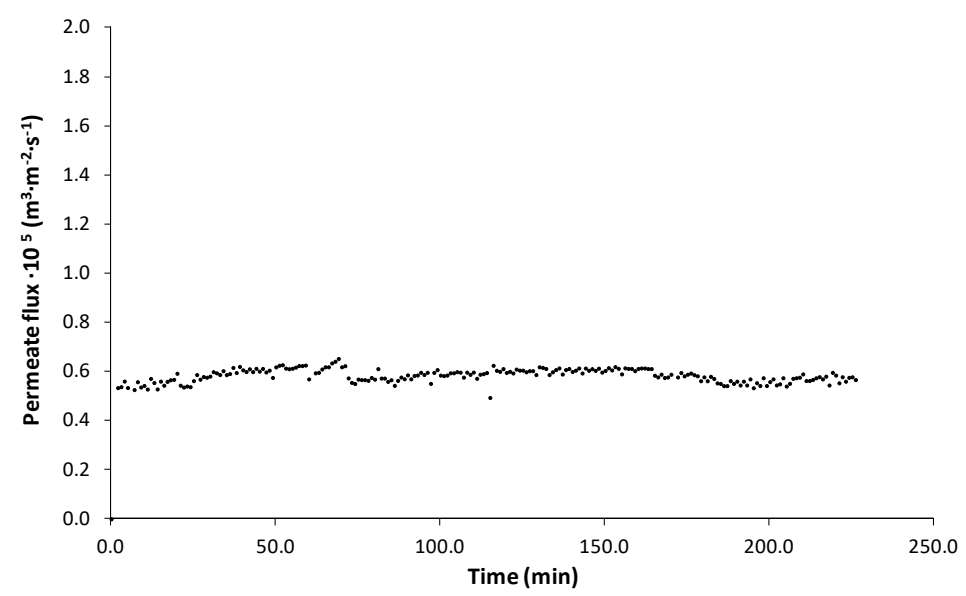

Figure 7. Evolution of the permeate flux in the NF treatment. 
The stationary permeate flux at the end of the NF test was $0.57 \times 10^{-5} \pm 0.02 \times 10^{-5} \mathrm{~m} \cdot \mathrm{s}^{-1}$ at 15 bar, $1.5 \mathrm{~m} \cdot \mathrm{s}^{-1}$ of cross flow velocity and $25^{\circ} \mathrm{C}$. This value was a $67.1 \%$ lower than the initial hydraulic permeate flux $\left(1.73 \times 10^{-5} \pm 0.08 \times 10^{-5} \mathrm{~m} \cdot \mathrm{s}^{-1}\right)$ at the same test conditions. Nevertheless, as shown in Figure 7, no flux decline was observed during the experiment. The absence of flux decline working with wastewater could be caused by the high salt concentration (Koyuncu et al., 2004). These authors worked with a wastewater containing salts and dye, obtaining a similar permeate flux evolution at $\mathrm{NaCl}$ concentrations up to 40 $\mathrm{g} \cdot \mathrm{L}^{-1}$. In our case, the $\mathrm{NaCl}$ concentration was around $70-80 \mathrm{~g} \cdot \mathrm{L}^{-1}$. At this high salt concentration the hydrophilicity of the membrane increases (Wiesner and Chellam, 1992) and the trend to cake layer formation on the membrane surface is reduced (Koyuncu et al., 2004).

The characterization of the NF permeate is shown in Table 4. It can be observed that the permeate stream keeps the same $\mathrm{pH}$ as the feed. The conductivity was only reduced $10.8 \pm$ $0.3 \%$. Thus, the salts rejection was very low, which is explained by the high salts concentrations in the feed. An increase of $\mathrm{NaCl}$ concentration leads to a decreased of the $\mathrm{NaCl}$ rejection (Cadotte et al., 1988). This fact enhances the recovery of a saline stream in NF permeate free from other compounds that are rejected by the membrane.

\section{b) COD and total phenols rejection}

The COD rejection was $45.9 \pm 1.9 \%$. This lower COD rejection could be attribute to the high salinity (Majewska-Nowak et al., 1996). The T.Ph concentration was negligible in the permeate stream. The colour, after 40 times dilution, was not detected. The same parameter 
was measured directly without dilution, and the FZ value was 0.001 . This means that the colour elimination was practically complete.

Although it has been taken into account the dilution of the samples in order to reduce the interferences by the high chloride concentration, at this low COD concentration the chloride concentration must be considered. Thus the COD associated to known concentrations of sodium chloride in model solutions was measured. Therefore, it was determined that the COD concentration in a sample of sodium chloride solution in water with the same conductivity as NF permeate, had a COD concentration of $320 \pm 12 \mathrm{mg} \cdot \mathrm{L}^{-1}$. In this way, it was estimated that the COD associated with organic matter in the NF permeate was $123 \pm 18$ $\mathrm{mg} \cdot \mathrm{L}^{-1}$.

Figure 8 summarizes the main results obtained in each step of the integrated system for the FTOP wastewaters treatment. It can be observed that in the final treated stream, the COD and T.Ph concentrations were reduced by $98.22 \%$ and $100 \%$, respectively. In addition, the turbidity and colour of the FTOP wastewaters were eliminated. The $\mathrm{NaCl}$ concentration in the permeate flux remained at level as fresh brine, since conductivity was $90.9 \mathrm{mS} \cdot \mathrm{cm}^{-1}$. On the other hand, as it is well known that the UF and the NF process remove viruses and bacteria (Rojas et al., 2008; Zio et al., 2005). Therefore, the permeate stream is basically a brine with the required $\mathrm{NaCl}$ concentration and only a $2 \%$ of lactic acid should be added to achieve the traditionally composition of the fresh brines used in the table olive processing (Panagou and Katsaboxakis, 2006). 


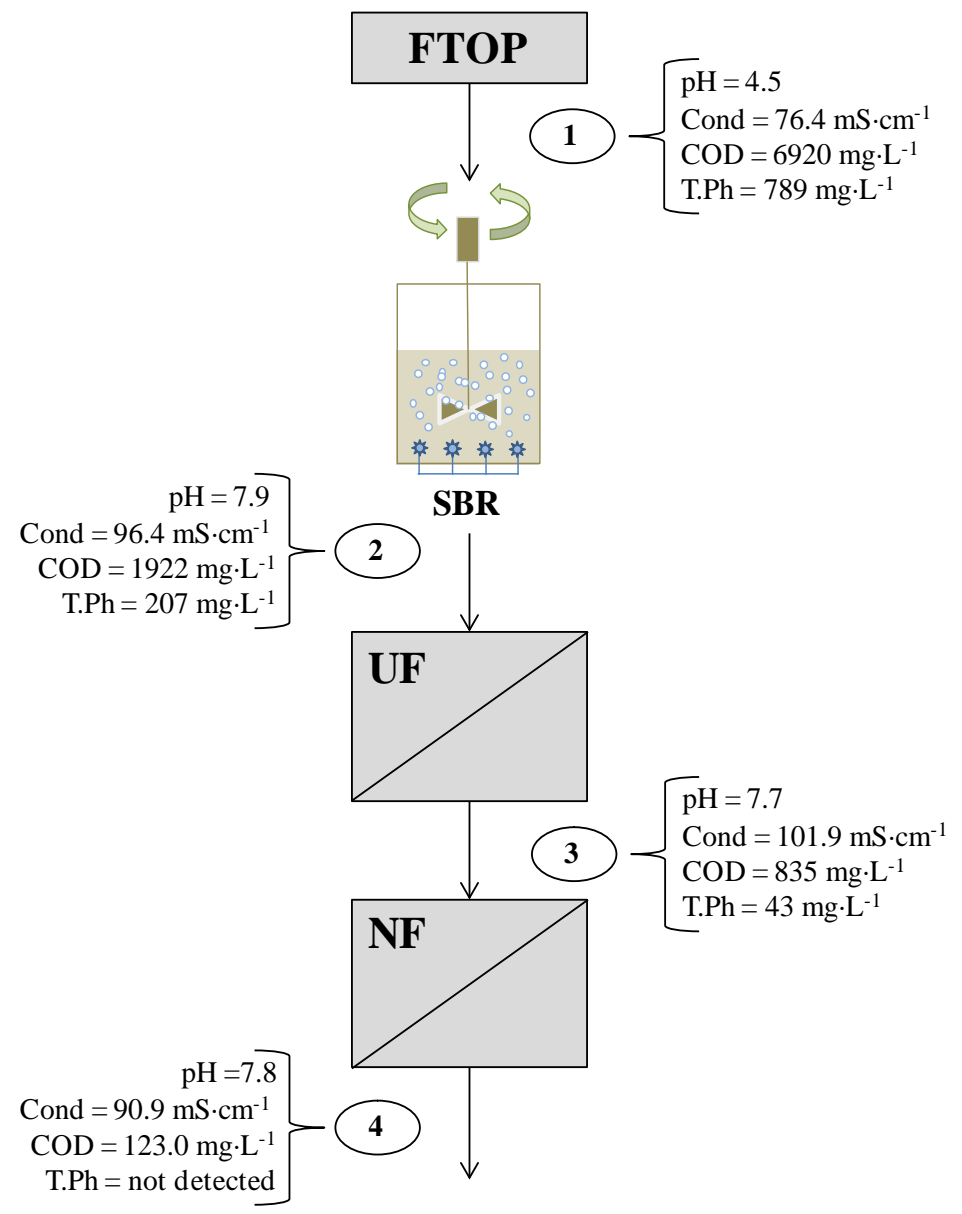

Figure 8. Integrated treatment for the FTOP wastewaters. Streams: (1) FTOP wastewater, (2) SBR effluent, (3) UF permeate, (4) NF permeate.

\section{CONCLUSIONS}

The fermentation brines from table olive processing wastewaters are very difficult to treat due to their enormous concentration in sodium chloride together with high COD and phenol compounds concentrations. Thus, in this work, an integrated process for the management of these effluents has been evaluated. The proposed hybrid system consisting of a biological treatment in a SBR and a combined membrane process, which included UF plus NF.

The biological treatment tests showed that in spite of the high COD and T.Ph. removal efficiencies (around 81 and 71\%, respectively), a considerable refractory organic matter 
concentration remains after the treatment. Thus membrane processes have to be used for the further treatment of the SBR effluent. Within the membrane processes, UF is the key process since severe fouling of the UF membranes occurred. However, it was mainly reversible and the used cleaning procedure restored the initial membrane permeability. By contrast, no fouling was observed in the used NF membrane. The final NF permeate stream had conductivity higher than $90 \mathrm{mS} \cdot \mathrm{cm}^{-1}$, COD associated to organic matter lower than 125 $\mathrm{mg} \cdot \mathrm{L}^{-1}$ and phenol compounds were non detected. Therefore, this effluent could be reused as brine in the table olive processing.

\section{Acknowledgments}

The authors of this work thank the financial support of CDTI (Centre for Development Technological Industrial) depending on the Spanish Ministry of Science and Innovation.

\section{References}

Aggelis, G.G., Gavala, H.N., Lyberatos, G., 2001. Combined and separate aerobic and anaerobic biotreatment of green olive debittering wastewater. J. Agric. Eng. Res. 80, 283-292. doi:10.1006/jaer.2001.0732

Ahmad, A.L., Ooi, B.S., Wahab Mohammad, A., Choudhury, J.P., 2004. Development of a highly hydrophilic nanofiltration membrane for desalination and water treatment. 
Desalination 168, 215-221. doi:10.1016/j.desal.2004.07.001

APHA, 2005. Standard Methods for the Examination of Water and Wastewater, 21st. ed. American Public Health Association, Washington, DC.

Bouaziz, M., Lassoued, S., Bouallagui, Z., Smaoui, S., Gargoubi, A., Dhouib, A., Sayadi, S., 2008. Synthesis and recovery of high bioactive phenolics from table-olive brine process wastewater. Bioorganic Med. Chem. 16, 9238-9246. doi:10.1016/j.bmc.2008.09.012

Brenes Balbuena, M., Garcia-Garcia, P., Garrido-Fernandez, A., 1988. Regeneration of Spanish Style green table olive brines by ultrafiltration. J. Food Sci. 53, 1733-1766. doi:10.1111/j.1365-2621.1988.tb07829.x

Brenes, M., García-García, P., Garrido-Fernández, A., 1989. Influence of reusing regenerated brines on some characteristics of the packing green olives. Grasas y Aceites 40, 182189.

Brenes, M., Rejano, L., Garcia, P., Sanchez, A., Garrido, A., 1995. Biochemical changes in phenolic compounds during Spanish-Style green olive processing. J. Agric. Food Chem. 43, 2702-2706. doi:10.1021/jf00058a028

Cadotte, J., Forester, R., Kim, M., Petersen, R., Stocker, T., 1988. Nanofiltration membranes broaden the use of membrane separation technology. Desalination 70, 77-88. doi:10.1016/0011-9164(88)85045-8

Carbonell-Alcaina, C., Corbatón-Báguena, M.-J., Álvarez-Blanco, S., Bes-Piá, M.A., Mendoza-Roca, J.A., Pastor-Alcañiz, L., 2016. Determination of fouling mechanisms in polymeric ultrafiltration membranes using residual brines from table olive storage wastewaters as feed. J. Food Eng. 187, 14-23. doi:10.1016/j.jfoodeng.2016.04.016 
Chiavola, A., Farabegoli, G., Antonetti, F., 2014. Biological treatment of olive mill wastewater in a sequencing batch reactor. Biochem. Eng. J. 85, 71-78. doi:10.1016/j.bej.2014.02.004

Corbatón-Báguena, M.J., Vincent-Vela, M.C., Álvarez-Blanco, S., Lora-García, J., 2013. Analysis of Two Ultrafiltration Fouling Models and Estimation of Model Parameters as a Function of Operational Conditions. Transp. Porous Media 99, 391-411. doi:10.1007/s11242-013-0192-4

Dạbrowski, A., Podkościelny, P., Hubicki, Z., Barczak, M., 2005. Adsorption of phenolic compounds by activated carbon - A critical review. Chemosphere 58, 1049-1070. doi:10.1016/j.chemosphere.2004.09.067

De Castro, A., Brenes, M., 2001. Fermentation of washing waters of spanish-style green olive processing. Process Biochem. 36, 797-802. doi:10.1016/S0032-9592(00)00280-6

Döepkens, E., Jonas, R., Jung, T., Krull, R., 2001. Rückführung von Abwasserteilströmen der Textilveredlung in den Produktionsprozess. GVC (Hrsg.), Prepr. Colloq. Produktionsintegrieter Wasser Abwasserechnik, “Nachhaltige Prod. der Textilveredlung” und “Membrantechnik”. Bremen B143-B15.

El-Abbassi, A., Khayet, M., Hafidi, A., 2011. Micellar enhanced ultrafiltration process for the treatment of olive mill wastewater. Water Res. 45, 4522-4530. doi:10.1016/j.watres.2011.05.044

El-Abbassi, A., Kiai, H., Raiti, J., Hafidi, A., 2014. Application of ultrafiltration for olive processing wastewaters treatment. J. Clean. Prod. 65, 432-438. doi:10.1016/j.jclepro.2013.08.016

El-Naas, M.H., Al-Muhtaseb, S. a., Makhlouf, S., 2009. Biodegradation of phenol by 
Pseudomonas putida immobilized in polyvinyl alcohol (PVA) gel. J. Hazard. Mater. 164, 720-725. doi:10.1016/j.jhazmat.2008.08.059

Fendri, I., Chamkha, M., Bouaziz, M., Labat, M., Sayadi, S., Abdelkafi, S., 2013. Olive fermentation brine: biotechnological potentialities and valorization. Environ. Technol. 34, 1-13. doi:10.1080/09593330.2012.689364

Ferrer-Polonio, E., García-Quijano, N.T., Mendoza-Roca, J.A., Iborra-Clar, A., 2016. Effect of alternating anaerobic and aerobic phases on the performance of a SBR treating effluents with high salinity and phenols concentration. Biochem. Eng. J. 113, 57-65. doi:10.1016/j.bej.2016.05.010

Ferrer-Polonio, E., Mendoza-Roca, J.A., Iborra-Clar, A., Alonso-Molina, J.., Pastor-Alcañiz, L., 2015. Comparison of two strategies for the start-up of a biological reactor for the treatment of hypersaline effluents from a table olive packaging industry. Chem. Eng. J. 273, 595-602. doi:10.1016/j.cej.2015.03.062

Field, R.W., Wu, D., Howell, J.A., Gupta, B.B., 1995. Critical flux concept for microfiltration fouling. J. Memb. Sci. 100, 259-272. doi:10.1016/0376-7388(94)00265Z

García-García, P., López-López, A., Moreno-Baquero, J.M., Garrido-Fernández, A., 2011. Treatment of wastewaters from the green table olive packaging industry using electrocoagulation. Chem. Eng. J. 170, 59-66. doi:10.1016/j.cej.2011.03.028

Günay, A., Çetin, M., 2013. Determination of aerobic biodegradation kinetics of olive oil mill wastewater. Int. Biodeterior. Biodegrad. 85, 237-242. doi:10.1016/j.ibiod.2013.07.012

Haddadi, A., Shavandi, M., 2013. Biodegradation of phenol in hypersaline conditions by Halomonas sp. strain PH2-2 isolated from saline soil. Int. Biodeterior. Biodegrad. 85, 
29-34. doi:10.1016/j.ibiod.2013.06.005

Ho, C., Zydney, A., 2000. A Combined Pore Blockage and Cake Filtration Model for Protein Fouling during Microfiltration. J. Colloid Interface Sci. 232, 389-399. doi:10.1006/jcis.2000.7231

International Olive Council [WWW Document], 2016. URL http://www.internationaloliveoil.org/estaticos/view/147-microsite?lang=en_US (accessed 1.1.16).

Jiraratananon, R., Anawat, S., Piyanoot, L., 2000. Performance evaluation of nanofiltration membranes for treatment of effluents containing reactive dye and salt. Desalination 130, $177-183$.

Kargi, F., Dinçer, A.R., 1998. Saline wastewater treatment by halophile-supplemented activated sludge culture in an aerated rotating biodisc contactor. Enzyme Microb. Technol. 22, 427-433. doi:10.1016/S0141-0229(97)00215-9

Kiai, H., Hafidi, A., 2014. Chemical composition changes in four green olive cultivars during spontaneous fermentation. LWT - Food Sci. Technol. 57, 663-670. doi:10.1016/j.lwt.2014.02.011

Kopsidas, G.C., 1992. Wastewaters from the preparation of table olives. Water Res. 26, 629631.

Koyuncu, I., Topacik, D., Wiesner, M.R., 2004. Factors influencing flux decline during nanofiltration of solutions containing dyes and salts. Water Res. 38, 432-440. doi:10.1016/j.watres.2003.10.001

Kumar, S., Zafar, M., Prajapati, J.K., Kumar, S., Kannepalli, S., 2011. Modeling studies on 
simultaneous adsorption of phenol and resorcinol onto granular activated carbon from simulated aqueous solution. J. Hazard. Mater. 185, 287-294.

doi:10.1016/j.jhazmat.2010.09.032

Lobos, J., Wisniewski, C., Heran, M., Grasmick, A., 2008. Sequencing versus continuous membrane bioreactors: Effect of substrate to biomass ratio $(\mathrm{F} / \mathrm{M})$ on process performance. J. Memb. Sci. 317, 71-77. doi:10.1016/j.memsci.2007.08.041

Majewska-Nowak, K., Kabsch-Korbutowicz, M., Winnicki, T., 1996. Salt effect on the dye separation by hydrophilic membranes. Desalination 108, 221-229. doi:10.1016/S00119164(97)00030-1

Malheiro, R., Sousa, A., Casal, S., Bento, A., Pereira, J.A., 2011. Cultivar effect on the phenolic composition and antioxidant potential of stoned table olives. Food Chem. Toxicol. 49, 450-457. doi:10.1016/j.fct.2010.11.023

Maretto, M., Blanchi, F., Vignola, R., Canepari, S., Baric, M., Iazzoni, R., Tagliabue, M., Petrangeli, M., 2014. Microporous and mesoporous materials for the treatment of wastewater produced by petrochemical activities. J. Clean. Prod. 77, 22-34. doi:10.1016/j.jclepro.2013.12.070

Marsilio, V., Lanza, B., 1998. Characterisation of an oleuropein degrading strain of Lactobacillus plantarum. Combined effects of compounds present in olive fermenting brines (phenols, glucose and $\mathrm{NaCl}$ ) on bacterial activity. J. Sci. Food Agric. 76, 520524. doi:10.1002/(SICI)1097-0010(199804)76:4<520::AID-JSFA982>3.0.CO;2-I

Maza-Márquez, P., Martínez-Toledo, M.V., González-López, J., Rodelas, B., Juárez-Jiménez, B., Fenice, M., 2013. Biodegradation of olive washing wastewater pollutants by highly efficient phenol-degrading strains selected from adapted bacterial community. Int. 
Biodeterior. Biodegrad. 82, 192-198. doi:10.1016/j.ibiod.2013.03.025

Moussavi, G., Barikbin, B., Mahmoudi, M., 2010a. The removal of high concentrations of phenol from saline wastewater using aerobic granular SBR. Chem. Eng. J. 158, 498504. doi:10.1016/j.cej.2010.01.038

Moussavi, G., khavanin, A., Alizadeh, R., 2010b. The integration of ozonation catalyzed with MgO nanocrystals and the biodegradation for the removal of phenol from saline wastewater. Appl. Catal. B Environ. 97, 160-167. doi:10.1016/j.apcatb.2010.03.036

Othman, N. Ben, Roblain, D., Chammen, N., Thonart, P., Hamdi, M., 2009. Antioxidant phenolic compounds loss during the fermentation of Chétoui olives. Food Chem. 116, 662-669. doi:10.1016/j.foodchem.2009.02.084

Panagou, E.Z., Katsaboxakis, C.Z., 2006. Effect of different brining treatments on the fermentation of cv. Conservolea green olives processed by the Spanish-method. Food Microbiol. 23, 199-204. doi:10.1016/j.fm.2005.03.003

Parinos, C.S., Stalikas, C.D., Giannopoulos, T.S., Pilidis, G.A., 2007. Chemical and physicochemical profile of wastewaters produced from the different stages of Spanishstyle green olives processing. J. Hazard. Mater. 145, 339-343. doi:10.1016/j.jhazmat.2006.12.061

Petrotos, K.B., Gkoutsidis, P.E., Kokkora, M.I., Giankidou, K.G., Tsagkarelis, A.G., 2012. A study on the kinetics of olive mill wastewater (OMWW) polyphenols adsorption on the commercial XAD4 macroporous resin. Desalin. Water Treat. 51, 2021-2029. doi:10.1080/19443994.2013.734479

Rivas, F.J., Beltrán, F.J., Alvarez, P., Frades, J., Gimeno, O., 2000. Joint aerobic biodegradation of wastewater from table olive manufacturing industries and urban 
wastewater. Bioprocess Eng. 23, 283-286. doi:10.1007/s004499900061

Rivas, F.J., Beltrán, F.J., Gimeno, O., Alvarez, P., 2003. Optimisation of Fenton’s reagent usage as a pre-treatment for fermentation brines. J. Hazard. Mater. B96, 277-290. doi:10.1016/S0304-3894(02)00217-0

Rojas, J.C., Moreno, B., Garral, G., 2008. Potabilization of low NOM reservoir water by ultrafiltration spiral wound membranes. J. Hazard. Mater. 158, 593-598. doi:10.1016/j.jhazmat.2008.01.107

Romero-Barranco, C., Brenes-Balbuena, M., García-García, P., Garrido Fernández, A., 2001. Management of spent brines or osmotic solutions. J. Food Eng. 49, 237-246. doi:10.1016/S0260-8774(00)00204-1

Ryan, D., Robards, K., Lavee, S., 1999. Changes in phenolic content of olive during maturation. Int. J. Food Sci. Technol. 34, 265-274. doi:10.1046/j.13652621.1999.00261.x

Santafé-Moros, A., Gozálvez-Zafrilla, J.M., 2010. Nano filtration study of the interaction between bicarbonate and nitrate ions. Desalination 250, 773-777. doi:10.1016/j.desal.2008.11.039

Sayadi, S., Allouche, N., Jaoua, M., Aloui, F., 2000. Detrimental effects of high molecularmass polyphenols on olive mill wastewater biotreatment. Process Biochem. 35, 725735. doi:10.1016/S0032-9592(99)00134-X

Segovia-Bravo, K.A., Jarén-Galán, M., García-García, P., Garrido-Fernández, A., 2010. Treatments to inhibit the browning reactions in model solutions of olive fruit extracts. Food Chem. 123, 741-746. doi:10.1016/j.foodchem.2010.05.044 
Segovia-Bravo, K.A., Jarén-Galán, M., García-García, P., Garrido-Fernández, A., 2009. Browning reactions in olives: Mechanism and polyphenols involved. Food Chem. 114, 1380-1385. doi:10.1016/j.foodchem.2008.11.017

Sharrer, M.J., Tal, Y., Ferrier, D., Hankins, J.A., Summerfelt, S.T., 2007. Membrane biological reactor treatment of a saline backwash flow from a recirculating aquaculture system. Aquac. Eng. 36, 159-176. doi:10.1016/j.aquaeng.2006.10.003

Singleton, V., Orthofer, R., Lamuela-Raventós, R.M., 1999. Analysis of total phenols and other oxidation substrates and antioxidants by means of Folin-Ciocalteu reagent. Methods Enzymol. 299, 152-178. doi:org/10.1016/S0076-6879(99)99017-1

Sivasubramanian, S., Namasivayam, S.K.R., 2015. Phenol degradation studies using microbial consortium isolated from environmental sources. J. Environ. Chem. Eng. 3, 243-252. doi:10.1016/j.jece.2014.12.014

Van Der Bruggen, B., Vandecasteele, C., 2001. Flux decline during nanofiltration of organic components in aqueous solution. Environ. Sci. Technol. 35, 3535-3540. doi:10.1021/es0100064

Vlyssides, A.G., Loizides, M., Karlis, P.K., 2004. Integrated strategic approach for reusing olive oil extraction 12, 603-611. doi:10.1016/S0959-6526(03)00078-7

Wang, Y.-F., Wang, X.-L., Li, H., Lin, K.-F., Wang, P., Yang, J., Liu, Y.-D., Sun, Z.-Y., Fan, L.-H., Wu, Z.-M., 2014. Treatment of high salinity phenol-laden wastewater using a sequencing batch reactor containing halophilic bacterial community. Int. Biodeterior. Biodegradation 93, 138-144. doi:10.1016/j.ibiod.2014.04.010

Wiesner, M.R., Chellam, S., 1992. Mass transport considerations for pressure-driven membrane processes. J. Am. Water Work. Assoc. 84, 88-95. 
Woolard, C.R., Irvine, R.L., 1995. Treatment of hypersaline wastewater in the sequencing batch reactor. Water Res. 29, 1159-1168.

Zio, A. Di, Prisciandaro, M., Barba, D., 2005. Disinfection of surface waters with UF membranes. Desalination 179, 297-305. doi:10.1016/j.desal.2004.11.075

Zuriaga-Agustí, E., Alventosa-deLara, E., Barredo-Damas, S., Alcaina-Miranda, M.I., IborraClar, M.I., Mendoza-Roca, J.A., 2014. Performance of ceramic ultrafiltration membranes and fouling behavior of a dye-polysaccharide binary system. Water Res. 54, 199-210. doi:10.1016/j.watres.2014.01.064 